\title{
LAYANAN BIMBINGAN KELOMPOK UNTUK MENINGKATKAN PENYESUAIAN SOSIAL SISWA
}

Oleh:

\author{
Ayu Andira ${ }^{1)}$, Waode Suarni ${ }^{2)}$ \\ 1) 2) Jurusan Bimbingan dan Konseling
}

Fakultas Keguruan dan Ilmu Pendidikan, Universitas Halu Oleo

Email : ${ }^{1)}$ ayuandirakonseling@gmail.com ${ }^{2}$ waodesuarni@yahoo.com

\begin{abstract}
ABSTRAK
Penelitian ini bertujuan untuk meningkatkan penyesuaian sosial siswa kelas X SMA Negeri 1 Loghia melalui bimbingan kelompok. Subjek dalam penelitian ini berjumlah 8 orang siswa. Jenis penelitian ini adalah penelitian pre eksperimen dengan desain one-grup pre-test post-test. Data dikumpulkan dengan menggunakan angket penyesuaian sosial. Hasil uji hipotesis dengan menggunakan Wilcoxon signed rank dengan taraf signifikan $\alpha=0,05$ diperoleh $\mathrm{P}=0,05$ diperoleh $\mathrm{P}_{\text {value }}=0,012 . \mathrm{P}_{\text {value }}<\alpha(0,012<0,05)$ dengan demikian $\mathrm{H}_{0}$ ditolak. Maka dapat disimpulkan bahwa layanan bimbingan kelompok berpengaruh terhadap penyesuaian sosial siswa kelas X SMA Negeri 1 Loghia.
\end{abstract}

Kata Kunci: Penyesuaian Sosial, Bimbingan Kelompok

\section{GROUP GUIDANCE SERVICES TO IMPROVE STUDENTS SOCIAL ADJUSTMENT}

\begin{abstract}
The purpose of the research was to find out whether group guidance service can develop social adjustment of the students who have been studying at the Grade Tenth (Class X) of SMA Negeri 1 Loghia. The subjects of the study were 8 students. This was pre experimental research with one-group pre test and post-test designs. The data were collected through questionnaires on social adjustment. Based on the result of hypothesis test using Wilcoxon Signed Rank Test, it was found that it's significant was $a=0,05$ with its Pvalue $=0.012$. Pvalue $<a(0.012<0.05)$. The test result indicates that Ho is rejected. The result of the research can therefore be concluded that group guidance service can develop social adjustment of the students who have been studying at the Tenth Graders (Class X) of SMA Negeri 1 Loghia.
\end{abstract}

Keyword: Social Adjustment, Group Guidance 


\section{Pendahuluan}

Manusia adalah makhluk sosial yang perlu berkomunikasi dan berinteraksi dengan orang lain demi kelangsungan hidupnya. Karena pada dasarnya manusia memiliki keterbatasan dan sejak lahir sudah dibekali dengan naluri untuk berhubungan dengan orang lain. Proses kehidupan individu akan selalu diwarnai hubungan dengan orang lain pada lingkungan tertentu, baik dengan lingkungan keluarga, sekolah, maupun dengan masyarakat luas.

Saat individu memasuki masa remaja, terkadang individu mengalami berbagai masalah yang ada karena terjadi perubahan fisik, psikis, dan juga lingkungan sosial. Hubungan dengan orang lain itu akan berlangsung dengan sehat apabila individu memiliki kemampuan penyesuaian sosial yang memadai. Bagi siswa, usaha penyesuaian sosial dapat menjadi sulit dalam perkembangan sosial, seperti yang diungkapkan oleh Hurlock (2008 : 213), bahwa salah satu tugas perkembangan siswa yang tersulit yaitu yang berhubungan dengan penyesuaian sosialnya, sehingga siswa harus melakukan penyesuaian baru. Komunikasi merupakan syarat utama dalam setiap interaksi, interaksi dalam komunikasi akan lebih efektif apabila setiap orang yang terlibat dapat berperan aktif, dapat mengutarakan pikirannya, menanggapi pendapat orang lain secara spontan.

Penyesuaian sosial yang baik yang seharusnya dimiliki oleh siswa adalah (a) penampilan nyata melalui sikap dan tingkah laku yang nyata, bila perilaku sosial siswa, seperti yang dinilai berdasarkan standar kelompoknya, memenuhi harapan kelompok, mereka akan menjadi anggota yang diterima kelompok seperti keterampilan menjalin hubungan antar manusia, (b) penyesuaian diri terhadap berbagai kelompok, siswa yang dapat menyesuaikan diri secara sosial dengan baik terhadap berbagai kelompok baik kelompok teman sebaya maupun kelompok orang dewasa dianggap sebagai orang yang memunyai penyesuaian sosial yang baik seperti berpartisipasi dalam kegiatan kelompok, (c) sikap sosial, siswa harus menunjukkan sikap yang menyenangkan terhadap orang lain, terhadap partisipasi sosial, dan terhadap perannya terhadap kelompok sosial bila ingin dinilai sebagai orang dapat menyesuaikan diri dengan baik secara sosial seperti mampu menghargai dan menghormati orang lain, dan (d) kepuasaan pribadi, siswa harus puas terhadap kontak sosialnya dan terhadap peran yang dimainkannya dalam situasi sosial, baik sebagai pemimpin maupun sebagai anggota (Hurlock dalam Yanizon, 2014: 2-3).

Manfaat bagi siswa jika memiliki penyesuaian sosial yang baik adalah perilaku siswa tersebut dapat mencerminkan keberhasilan dalam proses sosialisasi sehingga cocok dengan tempat mereka menggabungkan diri dan diterima sebagai anggota kelompok maupun anggota masyarakat. Jika dikaitkan dengan lingkungan sekolah, manfaat yang diperoleh adalah siswa memunyai sikap saling menghargai dan menerima hubungan interpersonal dengan guru, pembimbing, teman sebaya, menaati peraturan sekolah dan berpartisipasi aktif dalam kegiatan belajar dan kegiatan lainnya di sekolah. Penyesuaian sosial siswa yang baik akan memberikan dampak positif terhadap penerimaan siswa dalam kelompoknya.

Berdasarkan hasil wawancara kepada guru Bimbingan dan Konseling (BK), di Sekolah Menengah Atas (SMA) Negeri 1 Loghia pada tanggal 24 September 2018 terdapat berbagai masalah pada siswa salah satunya adalah masalah penyesuaian sosial yang rendah, di ukur dari penyebaran angket screening di sekolah didapatkan siswa yang memiliki penyesuaian sosial yang rendah sebanyak 31 dari 162 siswa. Adapun fenomena yang terjadi di sekolah tersebut secara individual yaitu tidak terbuka pada orang lain, kurang percaya diri dalam mengemukakan pendapat, suka mengganggu teman dengan katakata kasar seperti memanggil dengan memakai nama orang tua, jarang berkomunikasi dengan teman sebaya, tidak mampu berkomunikasi dengan baik dengan orang lain.

Berdasarkan uraian di atas, penelitian ini mengambil judul tentang "Layanan Bimbingan Kelompok Untuk Meningkatkan Penyesuaian Sosial Siswa". Tujuan dari penelitian ini adalah untuk mengetahui keberhasilan pelaksanaan layanan bimbingan kelompok dalam meningkatkan penyesuaian sosial siswa.

Agustiani (2006: 147) mengemukakan bahwa penyesuaian sosial merupakan penyesuaian yang dilakukan individu terhadap lingkungan di luar dirinya, seperti lingkungan rumah, sekolah dan masyarakat. Kartono (dalam Yuliantini, 2017: 393) mengemukakan bahwa penyesuaian sosial ialah: “(a) penjalinan secara harmonis suatu relasi dengan lingkungan sosial, (b) mempelajari tingkah laku yang diperlukan atau mengubah kebiasaan yang ada, sedemikian rupa, sehingga cocok bagi suatu masyarakat sosial". 
Hurlock (2015: 287) mengemukakan penyesuaian sosial ialah keberhasilan seseorang untuk menyesuaiakan diri terhadap orang lain pada umumnya dan terhadap kelompoknya pada khususnya, orang yang dapat menyesuaikan diri dengan baik mempelajari berbagai keterampilan sosial seperti kemampuan untuk menjalin hubungan komunikasi.

Berdasarkan beberapa pendapat di atas, peneliti menyimpulkan bahwa penyesuaian sosial adalah interaksi terhadap lingkungan di luar dirinya, baik itu berinteraksi teman sebaya, masyarakat dan lingkungan sekolah secara baik dan berkomunikasi secara baik terhadap orang lain. Orang yang berhasil melakukan penyesuaian sosial dengan baik, maka mengembangkan sikap sosial yang menyenangkan seperti mampu berinteraksi dengan baik kepada orang lain.

Hurlock (dalam Yanizon, 2014: 2-3) mengatakan bahwa terdapat empat kriteria dalam menentukan sejauh mana penyesuaian sosial seseorang mencapai ukuran baik dan sehat, yaitu sebagai berikut :

1. Penampilan nyata melalui sikap dan tingkah laku yang nyata

Perilaku sosial individu sesuai dengan standar kelompok atau memenuhi harapan kelompok maka individu akan diterima sebagai anggota kelompok. Bentuk dari penampilan nyata adalah (a) keterampilan menjalin hubungan antara manusia seperti kemampuan berkomunikasi, dan (b) kesedian untuk terbuka pada orang lain, dalam hal ini menerima dan memberi informasi.

2. Penyesuaian diri terhadap berbagai kelompok

Siswa yang dapat menyesuaikan diri secara sosial dengan baik terhadap berbagai kelompok baik kelompok teman sebaya maupun kelompok orang dewasa dianggap sebagai orang yang memunyai penyesuaian sosial yang baik. Bentuk dari penyesuaian diri terhadap berbagai kelompok seperti (a) berpartisipasi dalam kegiatan kelompok yaitu proses beregu (berkelompok) yang mana anggota-anggotanya mendukung dan saling mengandalkan untuk mencapai suatu hasil mufakat, dan (b) dapat bertanggung jawab terhadap kelompok.

3. Sikap sosial

Individu dapat menunjukkan sikap yang menyenangkan terhadap orang lain, terhadap partisipasi sosial, serta terhadap perannya dalam kelompok maka individu akan menyesuaikan diri dengan baik secara sosial. Bentuk dari sikap sosial adalah dapat menghargai dan menghormati orang lain.

4. Kepuasan pribadi

Individu harus dapat menyesuaikan diri dengan baik secara sosial, merasa puas terhadap kontak sosialnya dan terhadap peran yang dimainkannya dalam situasi sosial. Bentuk dari kepuasan pribadi adalah (a) memiliki kepercayaan diri, dan (b) memiliki kedisiplinan diri.

Selanjutnya, Schneiders (dalam Gunarta, 2015: 186) mengemukakan bahwa ada lima aspek penyesuaian sosial sebagai berikut:

1. Recognition adalah menghormati dan menerima hak-hak orang lain.

Dalam hal ini individu tidak melanggar hakhak orang lain yang berbeda dengan dirinya, untuk menghindari terjadinya konflik sosial. Ketika kita dapat menghargai dan menghormati hak-hak orang lain maka orang lain akan menghormati dan menghargai hak-hak kita sehingga hubungan sosial antar individu dapat terjalin dengan sehat dan harmonis.

2. Participation adalah melibatkan diri dalam berelasi.

Setiap individu harus dapat mengembangkan dan melihara persahabatan. Seseorang yang tidak mampu membangun relasi dengan orang lain dan lebih menutup diri dari relasi sosial akan menghasilkan penyesuaian diri yang buruk. Individu ini tidak memiliki ketertarikan untuk berpartisipasi dengan aktivitas di lingkungannya serta tidak mampu untuk mengekspresikan diri mereka sendiri, sedangkan bentuk penyesuaian akan dikatakan baik apabila individu tersebut mampu menciptakan relasi yang sehat dengan orang lain, mengembangkan persahabatan, berperan aktif dalam kegiatan sosial, serta menghargai nilai-nilai yang berlaku dimasyarakat.

3. Social approval adalah minat dan simpati terhadap kesejahteraan orang lain.

Hal ini dapat merupakan bentuk penyesuaian diri di masyarakat, dimana individu dapat peka dengan masalah dan kesulitan orang lain di sekelilingnya serta bersedia membantu meringankan masalahnya. Selain itu individu juga harus menunjukkan minat terhadap tujuan, harapan dan aspirasi, cara pandang ini juga sesuai dengan tuntutan dalam penyesuaian keagamaan (religious adjustment). 
4. Altruisme adalah memiliki sifat rendah hati dan tidak egois.

Rasa saling membantu dan mementingkan orang lain merupakan nilai-nilai moral yang aplikasi dari nilai-nilai tersebut merupakan bagian dari penyesuaian moral yang baik. Bentuk dari sifat-sifat tersebut memiliki rasa kemanusian, rendah diri, dan kejujuran dimana individu yang memiliki sifat ini akan memiliki kestabilan mental, keadaan emosi yang sehat dan penyesuaian yang baik

5. Conformity adalah menghormati dan mentaati nilai-nilai integritas hukum, tradisi dan kebiasaan.

Schneiders (dalam Ali dan Asrori, 2017: 181189) mengelompokkan faktor-faktor yang memengaruhi penyesuaian sosial sebagai berikut:

1. Kondisi fisik meliputi:

a. Hereditas dan konstitusi fisik; dalam mengidentifikasi pengaruh hereditas, digunakan pendekatan fisik karean hereditas dipandang lebih dekat dan tak terpisahkan oleh mekanisme fisik. Dari sini berkembang prinsip umum bahwa semakin dekat kapasitas pribadi, sifat atau kecenderungan berkaitan dengan konstitusi fisik maka akan semakin besar pengaruhnya terhadap penyesuaian diri dan sosial.

b. Kesehatan fisik; kualitas penyesuaian sosial yang baik dapat diperoleh dan dipelihara dalam kondisi kesehatan jasmani yang sehat. Orang yang memiliki penyakit jasmani kemungkinan memiliki kurang percaya diri, perasaan rendah diri, ketergantungan, dan perasaan ingin diperhatikan oleh orang lain. Namun tidak semua orang yang memiliki penyakit jasmani tidak dapat menyesuaikan dengan baik.

2. Kepribadian, meliputi:

a. Kemauan dan kemampuan untuk berubah; sebagai suatu proses yang dinamis, penyesuaian diri dan sosial membutuhkan kecenderungan untuk berubah dalam bentuk kemauan, perilaku, sikap dan karakteristik sejenis lainnya.

b. Pengaturan diri dan realisasi diri; kemampuan pengaturan diri mengimplikasikan potensi dan kemampuan ke arah realisasi diri. Kemampuan pengaturan diri dapat mencegah individu dari keadaan malasuai dan penyimpangan kepribadian.

3. Edukasi dan pendidikan, meliputi:

a. Belajar; kemauan belajar merupakan unsur penting dalam penyesuaian individu karena pada umumnya respons-respons dan sifat-sifat kepribadian yang diperlukan bagi penyesuaian diperoleh dan menyerap ke dalam diri individu melalui proses belajar.

b. Latihan; tidak jarang sesorang yang sebelumnya memiliki kemampuan penyesuaian yng kurang baik dan kaku, tetapi karena latihan secara sungguh-sungguh, akhirnya lambat laun menjadi bagus.

4. Lingkungan, meliputi:

a. Pengaruh rumah dan keluarga; lingkungan rumah dan keluarga merupakan faktor lingkungan yang paling besar pengaruhnya terhadap penyesuaian sosial siswa. Hal ini karena keluarga merupakan lingkungan pertama dan utama dalam kehidupan siswa.

b. Pengaruh masyarakat; lingkungan masyarakat merupakan tempat siswa bergerak, bergaul dan melakukan peran sosial. Pengaruh masyarakat merupakan kondisi-kondisi yang menentukan proses dan pola-pola penyesuaian sosial, dan

c. Pengaruh sekolah; sekolah memunyai peran yang penting dalam menentukan pola penyesuaian seseorang, karena sekolah memunyai peran sebagi medium untuk memengaruhi kehidupan intelektual, sosial dan moral siswa sehingga siswa diharapkan mampu meningkatkan kemampuan menyesuaikan sosial.

5. Agama dan budaya, meliputi:

a. Faktor budaya; faktor kebudayaan memunyai pengaruh terhadap pembentukan watak dan tingkah laku individu yang diperoleh melalui media pendidikan dalam keluarga, sekolah dan masyarakat secara bertahap dipengaruhi oleh faktor-faktor kebudayaan, dan

b. Pengaruh agama; agama merupakan sumber nilai, kepercayaan dan pola-pola tingkah laku yang akan memberikan arti, tujuan dan kestabilan hidup kepada umat manusia. Agama memberikan suasana psikologis tertentu dalam mengurangi konflik, frustasi dan ketegangan lainnya kemudian memberikan suasana tenang dan damai.

Sukardi (2000: 48) mengemukakan bahwa bimbingan kelompok yaitu layanan bimbingan yang memungkinkan sejumlah pesrta didik secara bersama-sama memeroleh berbagai bahan dari narasumber tertentu (terutama pembimbing/ konselor) yang berguna untuk menunjang kehidupannya sehari-hari baik individu maupun sebagai pelajar, anggota keluarga dan masyarakat serta untuk pertimbangan dalam pengambilan keputusan. 
Tohirin (2015: 164), mengatakan bahwa layanan bimbingan kelompok merupakan suatu cara memberikan bantuan (bimbingan) kepada individu (siswa) melalui kegiatan kelompok. Dalam layanan bimbingan kelompok, aktivitas dan dinamika kelompok harus diwujudkan untuk membahas berbagai hal yang berguna bagi pengembangan atau pemecahan masalah individu yang menjadi peserta layanan.

Prayitno dan Amti (2013: 309), menyatakan bahwa bimbingan kelompok yaitu layanan bimbingan dan konseling yang memungkinkan sejumlah peserta didik secara bersama-sama melalui dinamika kelompok memeroleh berbagai bahan dari narasumber. Bimbingan kelompok adalah proses pemberian bantuan yang diberikan pada individu dalam situasi kelompok. Bimbingan kelompok ditujukan untuk mencegah timbulnya masalah pada siswa dan mengembangkan potensi siswa.

Dinamika kelompok merupakan suatu relasi atau penjalinan yang hangat dan secara terbuka yang berlangsung secara bersama dari anggota kelompok dan saling memerhatikan sikap-sikap manusia dalam kelompok kecil dengan kekuatan berada didalam kelompok, penyebab tumbuhnya kekuatan tersebut, dan akibat terhadap individu, kelompok atau lingkungannya. Dinamika kelompok mengarahkan anggota-anggota kelompok untuk melakukan hubungan interpersonal satu sama lain. Jalinan hubungan interpersonal tersebut merupakan wadah bagi para anggota untuk berbagi maupun menerima berbagai pengetahuan, pengalaman serta perasaan satu sama lain sehingga memungkinkan terjadinya proses di dalam kelompok tersebut (Hartinah, 2009: 63-64).

Dinamika kelompok memunyai banyak arti, antara lain: belajar mengenai kekuatan-kekuatan sosial dalam suatu kelompok yang memperlancar atau menghambat proses kerja sama dalam kelompok, segala metode, sarana dan teknik yang dapat ditetapkan bila sejumlah orang bekerja sama dalam kelompok, misalnya berperan dan observasi terhadap jalannya proses kelompok dan pemberian umpan balik serta prosedur menangani organisasi dan pengeloaan suatu kelompok (Winkel dan Hastuti, 2006: 543).

Dinamika kelompok dapat ditandai dengan munculnya hal-hal sebagai berikut:

1. Kelompok yang diwarnai dengan dorongan yang tinggi dan kerjasama yang lancar,

2. Adanya saling percaya yang sangat tinggi antar anggota kelompok,
3. Antar anggota kelompok saling bersikap sebagai sahabat dalam arti yang sebenarnya, mengerti dan menerima secara positif tujuan bersama.

4. Anggota kelompok merasa memunyai semangat yang tinggi, nyaman dan aman sehingga mendorong rasa setia, saling menerima dan memberi, mau bekerja keras dan berkorban setiap anggota kelompok.

5. Komunikasi yang terjalin merupakan komunikasi yang efektif.

6. Anggota kelompok terlibat dalam suasana berpikir, merasa, bersikap, bertindak dan bertanggung jawab yang mendorong bagi tercapainya kebaikan bagi kelompok, dan

7. Jika timbul suatu persaingan antar anggota kelompok maka persaingan tersebut merupakan kompetitif dan sehat (Rangka dan Folastri, 2016: $10)$.

Hartinah (2009: 132-151) mengemukakan uraian gambaran empat tahap dari layanan bimbingan kelompok yaitu sebagai berikut:

1. Tahap pembentukan, yaitu dimulainya pengumpulan anggota kelompok dengan suasana yang hangat dan terbuka, dalam rangka penyusunan kegiatan kelompok yang akan direncanakan.

2. Tahap peralihan, yaitu setelah suasana kelompok terbentuk dan dinamis, kemudian suasana hangat dan terbuka tetap dipertahankan oleh kelompok maka hendaknya dibawa pemimpin kelompok membawa lebih jauh menuju kepada kegiatan kelompok sebenarnya yaitu tahap peralihan.

3. Tahap kegiatan, yaitu tahapan ini kegiatan kelompok untuk membahas topik-topik tertentu yang telah direncanakan. Anggota kelompok perlu didorong dan dirangsang untuk ikut serta dalam pembahasan secara penuh.

4. Tahap pengakhiran, kegiatan suatu kelompok tidak berlangsung secara terus-menerus tanpa berhenti. Setelah kegiatan kelompok memuncak pada tahap ketiga, kegiatan kelompok kemudian menurun dan selanjutnya kelompok akan mengakhiri kegiatannya pada saat yang dianggap tepat. Dalam tahap pengakhiran yang dibahas terkait dengan frekuensi pertemuan selanjutnya dan pembahasan keberhasilan kelompok.

Lebih lanjut Folastri dan Itsar (2016: 126147) mengemukakan pula tentang tahap-tahap dari bimbingan kelompok sebagai berikut:

1. Tahap pembentukan, yaitu dimulainya pengumpulan para (calon) konseli/ anggota 
kelompok dalam rangka kegiatan bimbingan dan konseling kelompok yang direncanakan. Pada tahap ini, pada umumnya para anggota kelompok saling memperkenalkan diri dan juga mengungkapkan tujuan ataupun harapanharapan yang ingin dicapai oleh masing-masing sebagian maupun seluruh anggota kelompok.

2. Tahap peralihan, dimana setelah suasana kelompok terbentuk dan dinamika kelompok sudah mulai tumbuh, kegiatan kelompok hendaknya dibawa lebih jauh oleh konselor/ pemimpin kelompok menuju kegiatan kelompok yang sebenarnya.

3. Tahap kegiatan, merupakan kehidupan yang sebenarnya dari kegiatan kelompok, dimana dalam tahap ketiga ini saling hubungan antar anggota kelompok diupayakan tumbuh dengan baik. Saling tukar pengalaman dalam bidang suasana perasaan yang terjadi, pengaturan, penyajian dan pembukaan diri berlangsung dengan bebas.

4. Tahap penyimpulan, yaitu tahap kegiatan untuk melihat kembali apa yang sudah dilakukan dan dicapai oleh kelompok.

5. Tahap pengakhiran, pada tahap ini kegiatan kelompok hendaknya dipusatkan pada pembahasan dan penjelajahan apakah para anggota kelompok akan mampu menerapkan hal-hal yang mereka telah pelajari (dalam suasana kelompok) pada kehidupan nyata sehari-hari.

Tohirin (2015:166) mengemukakan ada beberapa teknik yang bisa diterapkan dalam layanan bimbingan kelompok yaitu:

1. Pertama, teknik umum.

Dalam teknik ini dilakukan pegembangan dinamika kelompok. Perhatian yang cermat dalam tahapan pembentukan kelompok memiliki keterkaitan yang penting dengan hasil-hasil yang akan dicapai oleh kegiatan bimbingan kelompok. Secara garis besar teknik-teknik ini meliputi: (a) komunikasi interpersonal secara tepat, dinamis dan terbuka, (b) pemberian stimulus untuk menimbulkan inisiatif para anggota kelompok dalam membahas topik, berdiskusi, menganalisis dan berargumentasi, (c) pemberian semangat untuk menetapkan respon dan aktivitas anggota kelompok (d) pemberian penjelasan secara mendalam dan pemberian contoh untuk lebih memantapkan analisis, argumentasi dan pembahasan, (e) pelatihan dalam membentuk sikap atau perilaku yang baru.

2. Kedua, permainan kelompok.

Permainan dapat dijadikan sebagai salah satu teknik dalam layanan bimbingan kelompok baik sebagai selingan maupun sebagai wadah yang di dalamnya terdapat materi pembinaan atau materi layanan tertentu. Permainan kelompok yamg efektif dan dapat dijadikan sebagai teknik dalam layanan bimbingan kelompok harus memenuhi ciri-ciri sebagai berikut: (a) tidak menyulitkan para anggota, (b) memberikan suasana kebahagaiaan, (c) menimbulkan suasana rileks dan tidak melelahkan, (d) meningkatkan keakraban dan kepercayaan diri, serta (e) harus diikuti oleh semua anggota kelompok. Dalam permaian yang akan dilakukan, konselor atau anggota kelompok dapat secara kreatif mengembangkan bentuk-bentuk dan jenis-jenis permainan tertentu yang sesuai dengan topik bahasan yang telah disampaikan.

\section{Metode Penelitian}

Penelitian ini dilaksanakan di SMA Negeri 1 Loghia yang berada di lokasi Jalan Poros Napabale, Desa Waara Kecamatan Lohia selama enam bulan, dimulai dari bulan September 2018 hingga bulan Maret 2019.

Jenis penelitian ini adalah penelitian kuantitatif, dengan desain pra eksperimen model one group pre tes-post test design. Pra eksperimen merupakan desain penelitian yang dilakukan dengan jalan memberikan perlakuan kepada subjek tanpa adanya kelompok kontrol (Latipun, 2002: 68). Serta dengan menggunakan teknik one group pre test-post test desing karena variabel ini menawarkan hipotesis yang masuk akal (Julian dan Donald, 1966: 17)

Subjek dalam penelitian ini yaitu berjumlah 8 orang yang dipilih menggunakan teknik purposive sampling. Berdasarkan hasil dari penyebaran angket penyesuaian sosial (pre test) di sekolah, diperoleh 8 orang siswa, 5 orang yang penyesuaian sosial yang rendah dan 3 orang siswa yang memiliki penyesuaian sosial yang sedang, dengan maksud menciptakan kondisi yang efektif dan adanya timbal balik serta saling berbagi informasi kepada siswa mengenai dampak yang diakibatkan dari rendahnya penyesuaian sosial siswa.

Data penelitian yang digunakan adalah Angket Penyesuaian Sosial untuk mengetahui rendahnya penyesuaian sosial siswa. Angket disusun berdasarkan aspek-aspek penyesuaian 
sosial yang dikemukakan oleh Schneiders (dalam Gunarta, 2015: 186). Angket Penyesuaian Sosial ini terdiri dari 80 item pernyataan dan telah terlebih dahulu diuji coba di sekolah SMK Negeri 3 Kendari, untuk mengetahui valid suatu item yang di butuhkan dalam penelitian ini.

Angket Penyesuaian Sosial yang digunakan adalah model skala Likert yang terdiri dari 4 (empat) alternatif jawaban, yaitu: sangat sesuai (SS), sesuai (S) tidak sesuai (TS), sangat tidak sesuai (STS).

Teknik analisis data menggunakan analisis deskriptif persentase dan analisis statistik inferensial digunakan untuk menguji hipotesis penelitian. Pengujian hipotesis dilakukan dengan menggunakan statistika non parametik yaitu dengan uji wilcoxon signed rank untuk melihat ada tidaknya perbedaan gain score antara pre-test dan post-test pada kelompok eksperimen. Hal ini bertujuan untuk mengetahui perbedaan skor kontrol diri siswa pada saat sebelum diberikan treatment (pre-test), dan sesudah diberikan treatment (posttest).

\section{Hasil Penelitian dan pembahasan \\ Hasil Penelitian}

Analisis pre test penyesuaian sosial

Gambaran penyesuaian sosial siswa kelas

$\mathrm{X}^{-\mathrm{IPA}^{2}}$ dan X-IPS ${ }^{3}$ di SMA Negeri 1 Loghia, berdasarkan hasil pengisian Angket Penyesuaian Sosial dikonversikan dalam kategori penilaian dengan menggunakan analisis deskriptif persentase sebagaimana yang disajikan pada tabel berikut:

Tabel 1

Skor Pre test Siswa Sebelum diberikan Layanan Bimbingan Kelompok.

\begin{tabular}{|c|c|c|c|c|}
\hline No & Nama & Skor & $\%$ & $\begin{array}{c}\text { Kriteria } \\
\text { Pre test }\end{array}$ \\
\hline 1 & JA & 176 & $44 \%$ & Rendah \\
\hline 2 & WP & 156 & $39 \%$ & Rendah \\
\hline 3 & MA & 174 & $43,50 \%$ & Rendah \\
\hline 4 & NN & 229 & $57,25 \%$ & Sedang \\
\hline 5 & RI & 189 & $47,25 \%$ & Rendah \\
\hline 6 & NO & 179 & $44,75 \%$ & Rendah \\
\hline 7 & LI & 231 & $57,75 \%$ & Sedang \\
\hline 8 & DL & 232 & $58 \%$ & Sedang \\
\hline \multicolumn{2}{|c|}{ Rata-rata } & $\mathbf{1 9 6}$ & $\mathbf{4 8 , 9 3 \%}$ & Rendah \\
\hline
\end{tabular}

Berdasarkan data pada tabel 1 di atas, nampak penyesuaian sosial siswa kelas $X$ di SMA Negeri 1 Loghia sebelum diberi perlakuan (pre test) termaksud dalam kategori rendah. Dalam hal ini dapat dilihat dari rata-rata persentase penyesuaian sosial siswa mencapai $48,93 \%$ dari 8 orang subjek penelitian.

Analisis post test penyesuaian sosial

Gambaran penyesuaian sosial siswa kelas $\mathrm{X}$ di SMA Negeri 1 Loghia setelah diberikan perlakuan berupa layanan bimbingan kelompok dapat diketahui berdasarkan hasil analisis pernyesuaian sosial siswa, sebagaimana yang tertera pada tabel berikut:

Tabel 2

Skor Post Test Siswa Setelah diberikan Layanan Bimbingan Kelompok.

\begin{tabular}{|c|c|r|r|c|}
\hline No. & Nama & Skor & \multicolumn{1}{c|}{} & $\begin{array}{c}\text { Kriteria } \\
\text { Post test }\end{array}$ \\
\hline 1 & JA & 275 & $68,75 \%$ & Tinggi \\
\hline 2 & WP & 286 & $71,50 \%$ & Tinggi \\
\hline 3 & MA & 284 & $71 \%$ & Tinggi \\
\hline 4 & NN & 296 & $74 \%$ & Tinggi \\
\hline 5 & RI & 276 & $69 \%$ & Tinggi \\
\hline 6 & NO & 293 & $73,25 \%$ & Tinggi \\
\hline 7 & LI & 282 & $70,50 \%$ & Tinggi \\
\hline 8 & DL & 285 & $71,25 \%$ & Tinggi \\
\hline \multicolumn{6}{|c|}{ Rata-rata } & $\mathbf{2 8 5}$ & $\mathbf{7 1 , 1 5 \%}$ & Tinggi \\
\hline
\end{tabular}

Berdasarkan tabel 2, penyesuaian sosial siswa setelah diberikan perlakuan (post test) mengalami perubahan dari kategori rendah menjadi kategori tinggi. Hal ini dapat dilihat dari rata-rata persentase yang diperoleh yakni sekitar $71,15 \%$ dari 8 orang subjek penelitian.

Analisis statistik inferensial

Analisis data untuk mengetahui apakah layanan bimbingan kelompok dapat meningkatkan penyesuaian sosial siswa kelas X di SMA Negeri 1 Loghia dilakukan dalam Wilcoxon Signed Ranks adalah hasil signifikansi $\alpha=0,05$ diperoleh $\mathrm{P}_{\text {value }}=$ 0,012. $\mathrm{P}_{\text {value }}<\alpha(0,012<0,05)$ dengan demikian $\mathrm{H}_{\mathrm{o}}$ ditolak. Hal ini berarti layanan bimbingan kelompok dapat meningkatkan penyesuaian sosial siswa secara signifikan.

\section{Pembahasan}

Berdasarkan hasil analisis data dengan jumlah subjek penelitian sebanyak 8 siswa, dapat diketahui penyesuaian sosial siswa sebelum diberikan layanan bimbingan kelompok (pre test) 
termasuk dalam kategori rendah yaitu sebesar $48,93 \%$, sehingga penyesuaian sosial siswa perlu untuk ditingkatkan. Untuk meningkatkan penyesuaian sosial siswa, maka peneliti memberikan perlakuan layanan bimbingan kelompok.

Layanan bimbingan kelompok bertujuan untuk mengembangkan kemampuan siswa dalam bersosialisasi, khususnya kemampuan berkomunikasi peserta layanan terhadap orang lain, sehingga dapat meningkatkan penyesuaian sosial siswa. Melalui layanan bimbingan kelompok diharapkan siswa mendapatkan kesempatan untuk menggali dan berekspresi pada tiap topik materi yang diberikan pemimpin kelompok (Tohirin 2015: 165).

Setelah diberikan perlakuan (treatment) layanan bimbingan kelompok, siswa selanjutnya mengisi post test yang diberikan oleh peneliti. Tujuan dari pemberian post test adalah untuk mengetahui tingkat keberhasilan pelaksanaan perlakuan dan peningkatan penyesuaian sosial siswa. Berdasarkan hasil rata-rata penyesuaian sosial siswa setelah diberikan layanan bimbingan kelompok (post test) termasuk dalam kategori tinggi.

Berdasarkan hasil analisis data skor pre test dan skor post test tersebut maka dapat diketahui adanya peningkatan penyesuaian sosial siswa. Hal ini menunjukkan bahwa layanan bimbingan kelompok dapat meningkatkan penyesuaian sosial siswa di SMA Negeri 1 Loghia. Hal ini diperkuat dengan hasil analisis data statistik bahwa berdasarkan hasil perhitungan uji Wilcoxon Signed Rank Test pada tabel Test Statistics diperoleh nilai Asymp. Sig. (2-tailed) $=0,012<0.05$, artinya $\mathrm{H}_{\mathrm{a}}$ diterima. Dengan kata lain penyesuaian sosial siswa dapat ditingkatkan melalui layanan bimbingan kelompok.

Hasil penelitian ini juga memperkuat hasil penelitian yang dilakukan oleh Jayanti (2017) yang menunjukkan adanya peningkatan penyesuaian sosial setelah dilakukan layanan bimbingan kelompok yang berupa teknik sosiodrama. Dan hasil penelitian yang di lakukan oleh Nurfuad (2013) yang menunjukkan adanya peningkatan penyesuaian diri setelah dilakukan layanan bimbingan kelompok.

Hasil pengelolaan data secara keseluruhan, dari delapan orang siswa ditemukan 5 orang siswa masuk dalam kategori rendah dan 3 orang siswa masuk dalam kategori sedang. Setelah diberikan layanan bimbingan kelompok, dari 8 orang siswa, siswa yang berinisial WP mengalami peningkatan yang signifikan pada penyesuaian sosialnya. Pada pertemuan pertama WP mengalami rasa kurang percaya diri dan kurang berinteraksi terhadap teman-temannya. Setelah mengikuti lima kali pertemuan dalam layanan bimbingan kelompok, WP mengalami perubahan dari rasa tidak percaya diri menjadi percaya diri, dari kurangnnya berinteraksi dengan orang lain menjadi mudah berinteraksi.

Penyesuaian sosial siswa meningkat karena mereka sudah mampu menerima keadaan mereka sendiri, berpikir positif, terbuka pada orang lain, mulai bergaul dengan teman-teman lainnya. Hal ini sejalan dengan pernyataan dari WP saat proses pemberian layanan, dimana ia menyatakan bahwa sudah mulai berbaur dengan sesama temantemannya dan punya keberanian untuk aktif di kelas. Selain itu pula, dengan adanya layanan bimbingan kelompok, membantu siswa untuk berkembang ke arah yang lebih baik, dapat mengambil keputusan untuk dirinya sendiri, serta dapat menempatkan dirinya sesuai dengan lingkungan yang ada. Hal ini sejalan dengan pendapat yang dikemukakan oleh Abidin dan Budiyono, (2010: 63) bahwa layanan bimbingan kelompok dimaksudkan untuk memungkinkan individu diajak bersama-sama mengemukakan pendapat atau berani dalam berbicara serta bersama-sama membahas topik-topik penting berkaitan dengan permasalahan yang dialami, mengembangkan nilai-nilai kebersamaan, pembahasan bersama melalui dinamika kelompok, mengembangkan sikap dan tindakan yang nyata. Jadi semua keinginan kelompok tersebut dapat didiskusikan melalui dinamika kelompok untuk mencapai kebersamaan sekaligus kebutuhan pribadi.

\section{Kesimpulan dan Saran Kesimpulan}

Berdasarkan hasil dan pembahasan penelitian maka dapat disimpulkan bahwa layanan bimbingan kelompok dapat meningkatkan penyesuaian sosial siswa di SMA Negeri 1 Loghia.

\section{Saran}

\section{Bagi Guru BK}

Penelitian digunakan sebagai masukan bagi guru BK agar bisa menerapkan layanan bimbingan kelompok dalam menangani permasalahan siswa terutama menangani siswa 
yang memiliki penyesuaian sosial siswa yang rendah.

2. Bagi Siswa

Terapkan apa yang telah diperoleh melalui kegiatan bimbingan kelompok dalam kehidupan sehari-hari dengan melaksanakan penyesuaian sosial dengan baik dan positif serta berusaha untuk terus mengembangkan kemampuan serta keterampilan diri dalam berperilaku sosial yang baik agar dapat mengatasi masalah-masalah di kemudian hari.

3. Bagi Penelitian Selanjutnya

Dalam penelitian ini, untuk mengetahui data tentang penyesuaian sosial siswa hanya terbatas pada penggunaan angket sebagai metode pengumpulan data. Oleh karena itu, hendaknya kepada peneliti selanjutnya untuk dapat mengembangkan dengan menggunakan metode yang lain untuk mengukur tingkat penyesuaian sosial siswa.

\section{Daftar Pustaka}

Abidin, Zaenal dan Alief Budiyono. (2010). DasarDasar Bimbingan dan Konseling. Yogyakarta: Grafindo Litera Media

Agustiani, H. (2009). Psikologi Perkembangan: Pendekatan Ekologi Kaitannya dengan Konsep Diri dan Penyesuaian Diri pada Remaja. Bandung: PT Refika Aditama.

Asrori M dan Ali M. (2017). Psikologi Remaja: Perkembangan Peserta Didik. Jakarta: PT Bumi Aksara.

Bungin, B. (2014). Sosiologi Komunikasi. Jakarta: Kencana Prenadamedia Group.

Fitri. (2017). Pengaruh Penyesuaian Diri dan Penyesuaian Sosial terhadap Prestasi Akademik Siswa. Jurnal Riset Mahasiswa Bimbingan dan Konseling, Vol 3, No 8).

Folastri, Sisca dan Itsar Bolo Rangka. (2016). Prosedur Layanan Bimbingan dan Konseling Kelompok. Bandung. Mujahid Press.

Gunarta, E.M. (2015). Konsep Diri, Dukungan Sosial dan Penyesuaian Sosial Mahasiswa Pendatang di Bali. Jurnal Psikologi Indonesia Vol. 4, No. 02, hal 183-194.

Hartinah, Sitti. (2009). Konsep Dasar Bimbingan Kelompok. Bandung: PT. Refika Aditama.
Hurlock, Elizabeth .B. (2008). Psikologi Perkembangan: Suatu Pendekatan Rentang Kehidupan (Edisi Ke 5). Jakarta: Erlangga.

Jayanti, U. (2017). Bimbingan Kelompok Dengan Teknik Sosiodrama Untuk Meningkatkan Penyesuaian Sosial Peserta Didik Kelas VIII SMP Negeri 4 Bandar Lampung Tahun Pelajaram 2017/2018. Lampung: Universitas Islam Negeri Raden Intan.

Julian dan Donald. (1966). Experimental and quasi experimental desigs for research. Amerika: Hanbook of Research on Teaching.

Latipun. (2002). Psikologi Eksperimen. Yogyakarta: UMM Press.

Nurfuad, A. (2013). Meningkatkan Penyesuaian Diri Terhadap Lingkungan Sekolah Melalui Layanan Bimbingan Kelompok Pada Siswa Kelas VIII B SMP Negeri 2 Juwana Tahun 2012/2013. Semarang: Universitas Negeri Semarang.

Prayitno dan Erman Amti. (2013). Dasar-dasar Bimbingan dan Konseling: Jakarta. PT Rineka Cipta.

Sukardi, Dewa Ketut. (2000). Pengantar Pelaksanaan Program Bimbingan dan Konseling di Sekolah. Jakarta: Rineka Cipta.

Tohirin. (2015). Bimbingan dan Konseling di Sekolah dan Madrasah. Jakarta: Rajawali Pers.

Winkel WS dan Sri Hastuti MM. (2006). Bimbingan dan Konseling di Institusi Pendidikan. Yogyakarta: Media Abadi.

Yanizon, Ahmad. (2014). Peningkatan Penyesuaian Sosial Siswa Melalui Layanan Bimbingan Kelompok. Batam: FKIP UNRIKA.

Yuliantini, S. (2017). Hubungan Kecerdasan Emosi dan Penyesuaian Sosial dengan Kenakalan Remaja pada Siswa SMP PGRI 7 Samarinda Seberang. Psikoborneo.Vol. 5, No 2, hal 386399. 
JURNAL BENING VOLUME 4 NOMOR 2 JUNI 2020

ISSN : 2548-422

E-ISSN : 2716-1765 